\title{
Histopathological alterations in gills, liver, kidney and muscles of Ictalurus punctatus collected from pollutes areas of River
}

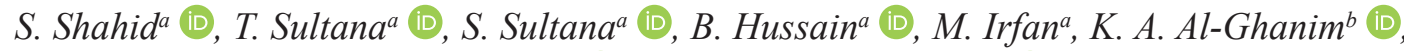 \\ F. A-Misned ${ }^{b}$ (D) and Shahid Mahboob ${ }^{a, b *}$ (D) \\ ${ }^{a}$ Government College University, Department of Zoology, Faisalabad, Pakistan \\ ${ }^{b}$ King Saud University, College of Science, Department of Zoology, Riyadh, Saudi Arabia \\ *e-mail: shahidmahboob60@hotmail.com
}

Received: February 20, 2020 - Accepted: April 19, 2020 - Distributed: August 31,2020

(With 19 figures)

\begin{abstract}
Untreated sewage and industrial wastes from Faisalabad city are disposed to River Chenab through Chakbandi Main Drain (CMD). The present project is planned to investigate the effects of this freshwater pollution on the body of fish Ictalurus punctatus. The specimens of this fish species were collected upstream and downstream of the entrance of CMD into River Chenab. Fish gills, liver, kidney and muscles from dorsolateral regions of fish were subjected to histopathology. Farmed fish and fish from upstream areas were used as control. Fish collected from polluted experimental sites showed significant damage in selected organs. Gill tissues showed an abnormality in the form of an uplifting of the primary epithelium, fusion, vacuolation, hypertrophy, and necrosis. While liver tissues subjected to hepatocytes degeneration, necrosis, mitochondrial granular hepatocyte, and sinusoids dilation. Kidney tissues indicated increased bowmen space and constricted glomerulus and degenerated nephrons. Edema, necrosis, and atrophy were observed in muscle tissues of fish from polluted areas. Fish from the upstream area showed fused gill lamellae, inflammatory cell infiltration, hypertrophy and vacuolation in hepatocytes. Kidney tissues indicated the presence of nuclear tubular cells, destructive renal tubules, hemorrhage, and necrosis at tubular epithelium. Intra myofibril spaces were also observed in muscles. Specimens of control fish indicated no variation in gills, liver, kidney, and muscles. The present study revealed a strong correlation between the degree of tissue damage and environmental contamination. Present findings also compel global warnings to protect our water bodies and fish to rescue the human population.
\end{abstract}

Keywords: catfish, histopathology, degeneration, haematoxylin, eosin.

\section{Alterações histopatológicas em brânquias, fígado, rim e músculos de Ictalurus punctatus coletados em áreas poluídas do rio}

\section{Resumo}

O esgoto não tratado e os resíduos industriais da cidade de Faisalabad, no Paquistão, são descartados no Rio Chenab através do dreno principal de Chakbandi (CMD). O presente projeto busca investigar os efeitos dessa poluição de água doce no corpo de peixes Ictalurus punctatus. Os espécimes deste peixe foram coletados a montante e a jusante da entrada do CMD no Rio Chenab. Brânquias, fígado, rim e músculos das regiões dorsolaterais dos peixes foram submetidos à histopatologia. Peixes de criação e peixes de áreas a montante foram utilizados como controle. Peixes coletados em locais experimentais poluídos mostraram danos significativos em órgãos selecionados. Os tecidos branquiais mostraram uma anormalidade na forma de elevação do epitélio primário, fusão, vacuolação, hipertrofia e necrose. Observou-se que os tecidos hepáticos estão sujeitos a degeneração de hepatócitos, necrose, hepatócitos mitocondriais granulares e dilatação de sinusoides. Os tecidos renais indicaram aumento do espaço dos arqueiros, glomérulos contraídos e néfrons degenerados. Edema, necrose e atrofia foram observados nos tecidos musculares de peixes de áreas poluídas. Peixes da área a montante apresentaram lamelas branquiais fundidas, infiltração de células inflamatórias, hipertrofia e vacuolização em hepatócitos. Os tecidos renais indicaram a presença de células tubulares nucleares, túbulos renais destrutivos, hemorragia e necrose no epitélio tubular. Os espaços intramiofibrilas também foram observados nos músculos. Amostras de peixes controle não indicaram variação em brânquias, fígado, rim e músculos. O presente estudo revelou uma forte correlação entre o grau de dano tecidual e a contaminação ambiental. As descobertas atuais também constituem avisos globais para proteger nossos corpos d'água e peixes para resguardar a população humana.

Palavras-chave: peixe-gato, histopatologia, degeneração, hematoxilina, eosina. 


\section{Introduction}

Water is being polluted because of municipal and industrial wastes. In Pakistan, the population having access to clean drinking water in urban areas is $56 \%$, while in a rural area, it is $45 \%$ (Farooq et al., 2008). In Pakistan about 2000 million gallons of sewage water per day has been added to surface waters (Martin et al., 2006). In Pakistan about 6634 industries are registered, out of which 1228 are regarded as extremely polluted Chenab River receives pollutants in the shape of sewage and industrial waste discharge of different districts and surrounded area through different drains. Faisalabad city adds sewage and industrial wastes to the Chenab River through CMD. Pollution directly communicates diseases to human such as respiratory, diarrhea, cardiovascular and neurological diseases (Ullah et al., 2014). Through feeding on polluted food harmful substance bio-accumulate in the food chain (Kim et al., 2016). These chemicals through food chain reach for human and leading to biomagnifications. Catfish is an ornamental fish with a high-quality food, value and a good source of vitamin D too (Miller and Mitchell, 2009). Catfish are bottom dweller and preferred to live with sand and gravel substrates. Histological variations act as a biomarker of freshwater contaminations. Direct and indirect effects on animal tissues can be determined through histopathology (Paithane et al., 2012; Schwaiger et al., 2004). This project was planned to estimate the effects of freshwater pollution on muscles, gills, kidney and liver of Ictalurus punctatus through histopathology.

\section{Material and Methods}

\subsection{Procurement of fish}

Chakbandi Main Drain (CMD) adds large amounts of toxic chemicals from a variety of industries and sewage wastes to River Chenab well sufficient to reduce the its water productivity by changing the water quality parameters necessary for the growth of aquatic flora and fauna. Fish were harvested from the Chenab River in Pakistan through its $30 \mathrm{~km}$ length upstream to CMD waste disposal and $30 \mathrm{Km}$ downstream towards Head Trimu at latitude $31.570^{\circ} \mathrm{N}$ and longitude $72.534^{\circ} \mathrm{E}$. Specimens of catfish were collected from these areas (04 sites) by using gill nets. Fish for control was collected from the Muzafarghar fish Hatchery. These specimens were brought to Research Laboratory, Department of Zoology,

\subsection{Water sampling}

Water samples were collected from each site of fish harvest in $1.5 \mathrm{~L}$ polyethylene water bottles with the help of a water sampler. These water samples were transported to the Fisheries Research Laboratory and analyzed within $24 \mathrm{~h}$ for selected heavy metals (Boyd, 1981). The concentration of metals was detected by metal kits (Spectroquant Analysis System, Merck) and using nitrous oxide/acetylene flame atomic absorption spectrophotometer (2000 series, High-Technologies Corporation, Chiyoda, Tokyo, Japan).

\subsection{Histopathology}

Following procedure was adopted for histopathology (Sultana et al., 2016). Gills, liver, kidney, muscle tissues were fixed in sera 4-6 hours. Fixation solution consisted of absolute alcohol, Formaldehyde, and glacial acetic acid in a ratio of $(60 \mathrm{ml}: 30 \mathrm{ml}: 10 \mathrm{ml})$, respectively. After fixation, tissue slices were tagged and subjected to dehydration in alcoholic ascending grades. Tissues were cleared and embedded in molds with paraffin wax for 45 to 60 minutes at $58{ }^{\circ} \mathrm{C}$ in oven. Bubbles were removed and wax blocks with embedding tissues were frozen for solidification. Tissues were cut at 2.5-micron sections by microtome. The sections were placed in oven at $37^{\circ} \mathrm{C}$ for overnight. Tissues were stained with haematoxylin stain and counter stained with Eosin. These sections were mounted with Canada balsam and cover slip was mounted on slides and placed in incubator for one night. Slides were examined under microscope and photographed at 10X-60X. The histopathological changes were observed by comparing with control and recent literature.

\section{Results and Discussion}

All water quality parameters analyzed downstream CMD were found enough higher than the permissible limits defined by WHO (2013) (Table 1). Experimental specimens showed several changes in gills, liver, kidney and muscle structure. Gills act as a barrier against toxins, it decreases the uptake of toxins and their magnification in other organs. Due to regular contact with water gills are directly exposed to pollution. Specimens of catfish collected from River Chenab downstream CMD indicated fusion of secondary lamellae, vacuolization and hypertrophy in the gills (Figure 1). While up lifting of primary epithelial (Figure 2) and fused gill lamellae, inflammatory cell infiltration and hypertrophy was observed in catfish collected from River Chenab upstream to the entrance of CMD (Figure 3). A control specimen of Ictalurus punctatus indicated normal histology of gills indicating primary lamellae of gills consist of mucous, epithelium and gill arch (Figure 4) and gill epithelium consisting of epithelial cells (Figure 5). Blood capillaries and pillar cells were also seen normal in secondary lamellae (Figure 6).

The liver is a major organ which performs metabolic functions. Heavy metals accumulate in the liver and produce different anomalies in it. Histopathology off downstream specimen's liver illustrated hepatocytes degeneration and increased number of mitochondria (Figure 7). Same tissues showed necrosis and sinusoids dilation (Figure 8). Vacuolization in hepatocytes was also seen in specimens of catfish collected from upstream to the entrance of CMD into River Chenab (Figure 9). Specimens of control fish showed normal hepatocytes, hepatic arteries and bile collecting ducts having distinct lobules (Figure 10). 
Kidneys have a major role in excretion and homeostasis. However, kidney tissues of catfish collected from downstream of CMD showed increased bowmen space and constricted glomerulus (Figure 11). Kidney tissues of upstream specimens showed nuclear tubular cells and destructive renal tubules (Figure 12) and haemorrhage (Figure 13). The control specimen showed normal nephrons with normal renal corpuscles, normal Bowmen's capillaries surrounding the glomerulus and forming normal glomerulus tufts (Figure 14).

Table 1. Comparison of mean of water quality parameters from experimental sites of River Chenab (mean $\pm \mathrm{SE}$ ).

\begin{tabular}{|c|c|c|c|c|}
\hline \multirow{2}{*}{ WQPs } & \multicolumn{2}{|c|}{ Upstream to CMD Sites } & \multicolumn{2}{|c|}{ Downstream to CMD Sites } \\
\hline & Site 1 & Site 2 & Site 3 & Site 4 \\
\hline $\mathrm{Ph}$ & $7.77 \pm 0.054 \mathrm{a}$ & $7.67 \pm 0.052 \mathrm{a}$ & $10.24 \pm 0.04 b$ & $10.38 \pm 0.03 b$ \\
\hline $\mathrm{BOD}(\mathrm{mg} / \mathrm{L})$ & $30.8 \pm 1.66 \mathrm{a}$ & $40.8 \pm 1.64 b$ & $61.07 \pm 1.88 \mathrm{c}$ & $69.07 \pm 1.86 \mathrm{c}$ \\
\hline $\mathrm{COD}(\mathrm{mg} / \mathrm{L})$ & $45.83 \pm 5.45 b$ & $47.83 \pm 5.42 b$ & $135.17 \pm 13.63 \mathrm{c}$ & $138.17 \pm 13.59 \mathrm{c}$ \\
\hline TDS (mg/L) & $1.043 \pm 0.061 \mathrm{a}$ & $1.051 \pm 0.058 \mathrm{a}$ & $2.322 \pm 0.057 b$ & $2.354 \pm 0.055 \mathrm{~b}$ \\
\hline TSS (mg/L) & $1.160 \pm 0.035 \mathrm{a}$ & $1.164 \pm 0.030 \mathrm{a}$ & $2.222 \pm 0.047 b$ & $2.252 \pm 0.043 b$ \\
\hline $\mathrm{TS}(\mathrm{mg} / \mathrm{L})$ & $2.203 \pm 0.096 \mathrm{~b}$ & $2.215 \pm 0.358 \mathrm{~b}$ & $4.544 \pm 0.104 \mathrm{~d}$ & $4.606 \pm 0.098 \mathrm{~d}$ \\
\hline Conductivity ( $\mu \mathrm{S} / \mathrm{cm})$ & $752.14 \pm 17.02 \mathrm{c}$ & $813.99 \pm 17.0 \mathrm{c}$ & $1445.02 \pm 18.1 \mathrm{~d}$ & $1953.09 \pm 18.03 \mathrm{e}$ \\
\hline Hardness (mg/L) & $192.86 \pm 4.52 b$ & $201.86 \pm 4.42 b$ & $546.19 \pm 8.15 \mathrm{c}$ & $576.19 \pm 8.12 \mathrm{c}$ \\
\hline $\mathrm{Co}(\mathrm{mg} / \mathrm{L})$ & $0.914 \pm 0.045 \mathrm{a}$ & $0.920 \pm 0.041 \mathrm{a}$ & $0.973 \pm 0.004 b$ & $0.979 \pm 0.003 b$ \\
\hline $\mathrm{Cu}(\mathrm{mg} / \mathrm{L})$ & $0.039 \pm 0.003 \mathrm{a}$ & $0.053 \pm 0.003 \mathrm{a}$ & $0.87 \pm 0.09 \mathrm{~b}$ & $0.95 \pm 0.09 \mathrm{~b}$ \\
\hline $\mathrm{Mn}(\mathrm{mg} / \mathrm{L})$ & $0.405 \pm 0.012 b$ & $0.438 \pm 0.011 \mathrm{~b}$ & $1.493 \pm 0.061 \mathrm{c}$ & $1.499 \pm 0.059 \mathrm{c}$ \\
\hline $\mathrm{Zn}(\mathrm{mg} / \mathrm{L})$ & $0.036 \pm 0.0015 \mathrm{a}$ & $0.103 \pm 0.001 \mathrm{~b}$ & $0.209 \pm 0.035 b$ & $0.217 \pm 0.030 \mathrm{c}$ \\
\hline $\mathrm{Pb}(\mathrm{mg} / \mathrm{L})$ & $0.0635 \pm 0.0055 b$ & $0.0653 \pm 0.005 \mathrm{~b}$ & $1.382 \pm 0.09 \mathrm{c}$ & $1.392 \pm 0.06 \mathrm{c}$ \\
\hline $\mathrm{Cr}(\mathrm{mg} / \mathrm{L})$ & $0.0345 \pm 0.005 \mathrm{a}$ & $0.0495 \pm 0.003 \mathrm{a}$ & $0.259 \pm 0.041 \mathrm{~b}$ & $0.265 \pm 0.037 \mathrm{~b}$ \\
\hline $\mathrm{Sn}(\mathrm{mg} / \mathrm{L})$ & $0.0035 \pm 0.001 \mathrm{a}$ & $0.0065 \pm 0.001 \mathrm{a}$ & $0.28 \pm 0.032 b$ & $0.31 \pm 0.030 \mathrm{~b}$ \\
\hline $\mathrm{Hg}(\mathrm{mg} / \mathrm{L})$ & $0.002 \pm 0.00 \mathrm{a}$ & $0.009 \pm 0.001 \mathrm{a}$ & $0.6673 \pm 0.021 \mathrm{c}$ & $0.6679 \pm 0.019 \mathrm{c}$ \\
\hline Ni (mg/L) & $0.05 \pm 0.005 \mathrm{~b}$ & $0.08 \pm 0.003 \mathrm{~b}$ & $0.218 \pm 0.006 \mathrm{c}$ & $0.229 \pm 0.006 \mathrm{c}$ \\
\hline $\mathrm{Cd}(\mathrm{mg} / \mathrm{L})$ & $0.0085 \pm 0.0015 \mathrm{a}$ & $0.01 \pm 0.0012 \mathrm{a}$ & $0.135 \pm 0.013 b$ & $0.140 \pm 0.011 b$ \\
\hline $\mathrm{Ph}(\mathrm{mg} / \mathrm{L})$ & $0.1 \pm 0.034 \mathrm{a}$ & $0.5 \pm 0.032 \mathrm{a}$ & $1.49 \pm 0.104 \mathrm{c}$ & $1.59 \pm 0.101 \mathrm{c}$ \\
\hline $\mathrm{SO}_{4}^{-2}(\mathrm{mg} / \mathrm{L})$ & $75.39 \pm 1.45 b$ & $78.40 \pm 1.46 b$ & $253.74 \pm 26.27 \mathrm{~d}$ & $253.88 \pm 26.25 \mathrm{~d}$ \\
\hline
\end{tabular}

Means sharing similar letter in a row belonging to particular parameter are statistically non significant $(\mathrm{P}>0.05)$. BOD: Biological Oxygen demand; COD: Chemical Oxygen demand; TDS: Total dissolve solids; TSS: Total suspended solids; TS: Total solids; WQPs: Water quality Parameters; CMD: Chakbandi Main Drain.

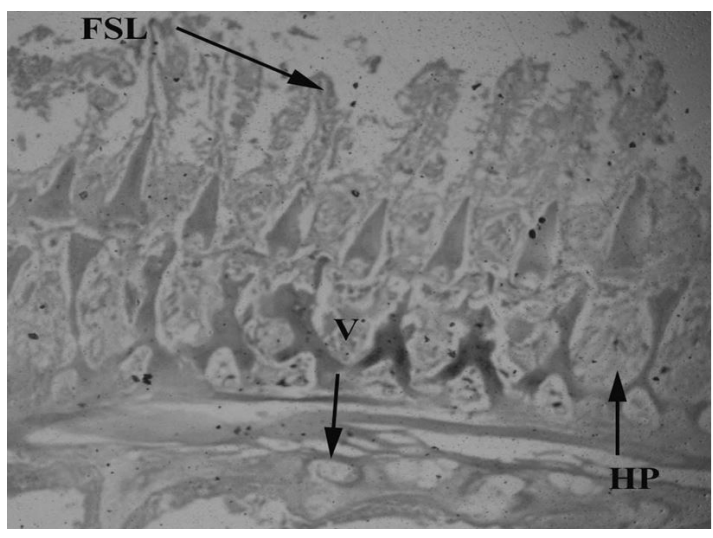

Figure 1. Ictalurus punctatus collected downstream to the entrance into River Chenab CMD showing damage in gill tissues i.e. fusion of secondary lamellae (FSL), vacuolization (V) and hypertrophy

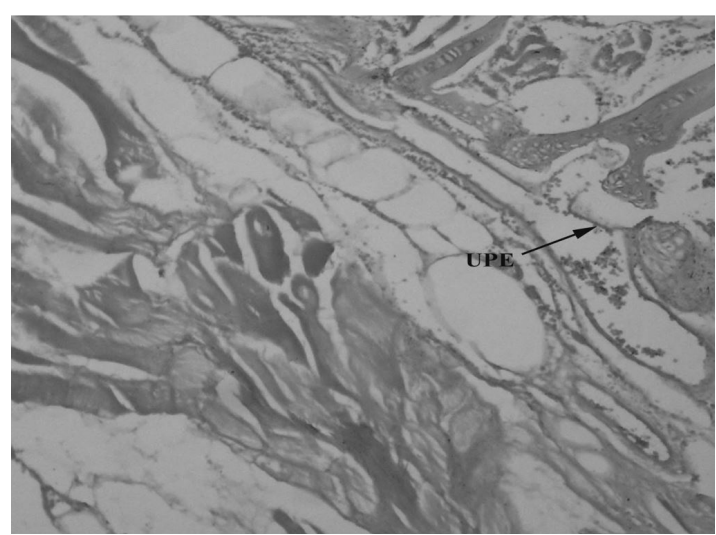

Figure 2. Ictalurus punctatus collected downstream to the entrance into River Chenab CMD showing damage in gill tissues i.e. up lifting of primary epithelium (UPE) 40X. 


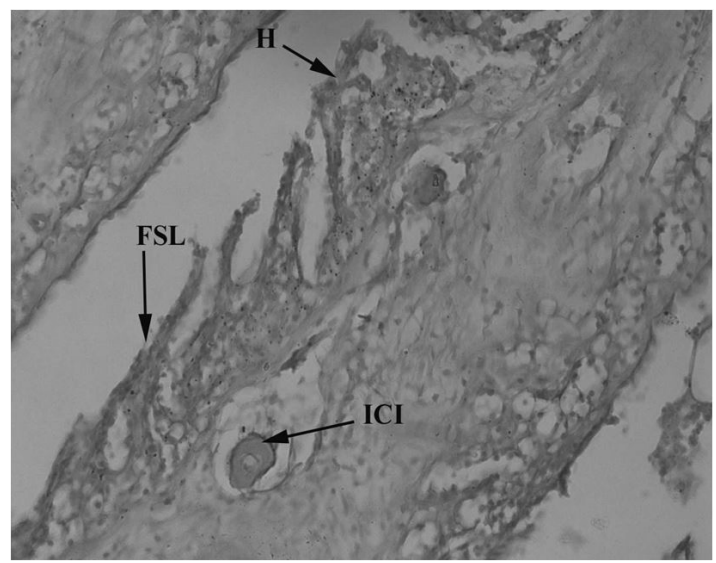

Figure 3. Ictalurus punctatus collected upstream of the entrance into River Chenab CMD showing damage in gill tissues i.e. fused secondary lamellae (FGL), inflammatory cell infiltration (ICI) and hypertrophy (H) 40X.

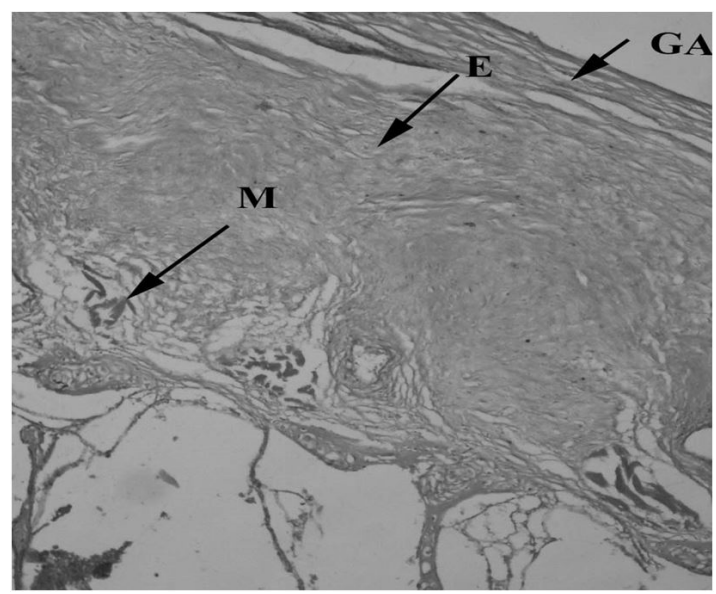

Figure 4. Control freshwater fish (Ictalurus punctatus) showing normal gill tissues with epithelial cells (E), mucus cell (M) and gill arch (GA) 40X.

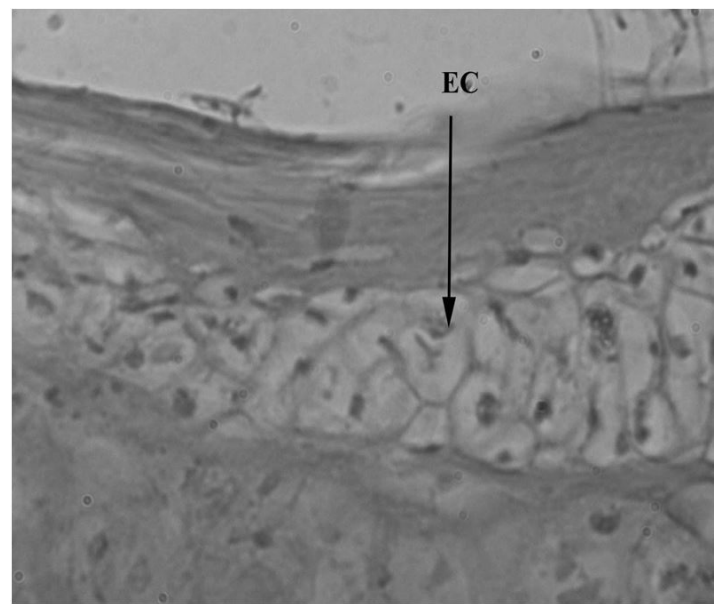

Figure 5. Control freshwater fish (Ictalurus punctatus) showing normal gill tissues with epithelial cells (EC) 100X.

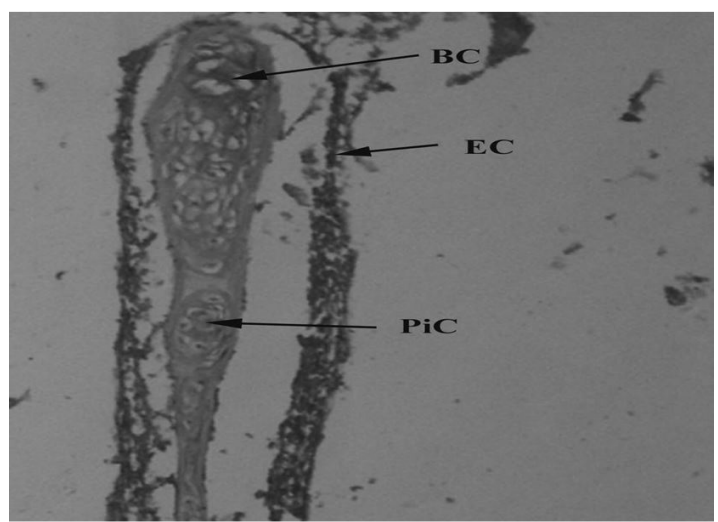

Figure 6. Control freshwater fish (Ictalurus punctatus) showing normal gill tissues with blood capillaries (BC), epithelial cells (EC) and pillar cells (PiC) 100X.

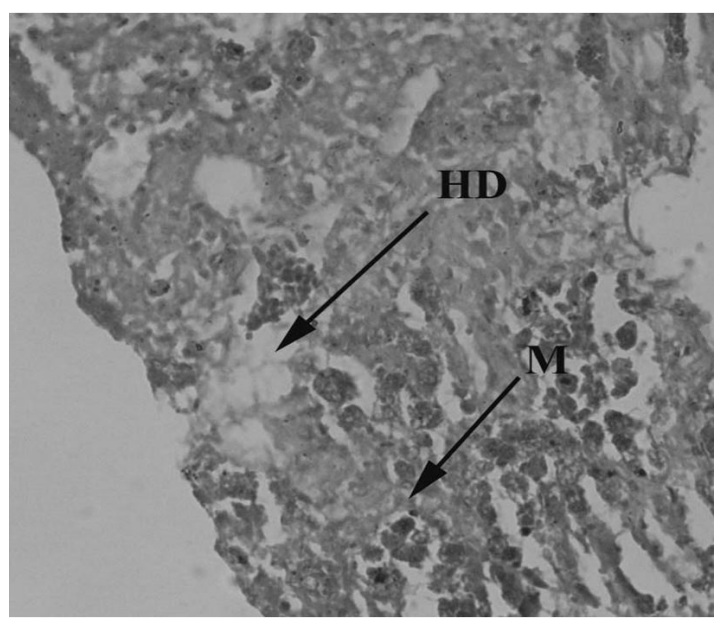

Figure 7. Ictalurus punctatus collected downstream to the entrance into River Chenab CMD showing damage in liver tissues with mitochondrial granular hepatocyte (M) and hepatocyte degeneration (HD) $40 X$.

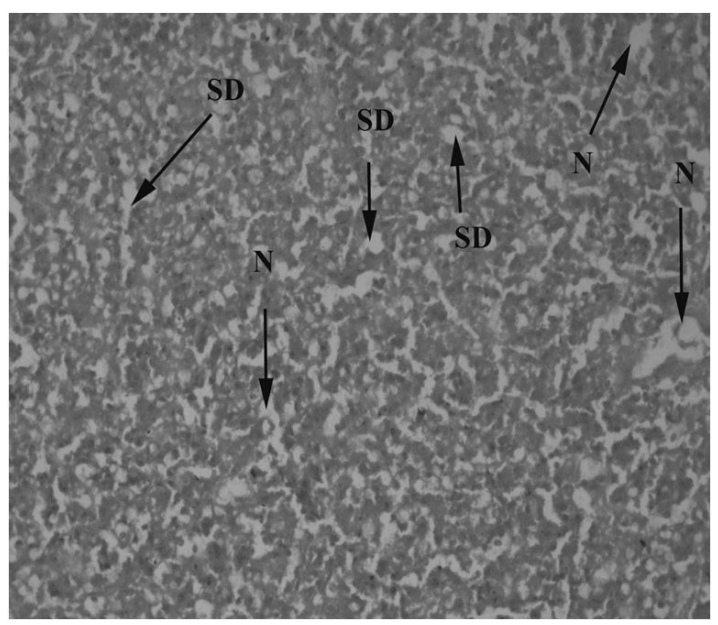

Figure 8. Ictalurus punctatus collected downstream to the entrance into River Chenab CMD showing damage in liver tissues with sinusoid dilation (SD) and necrosis (N) 40X. 


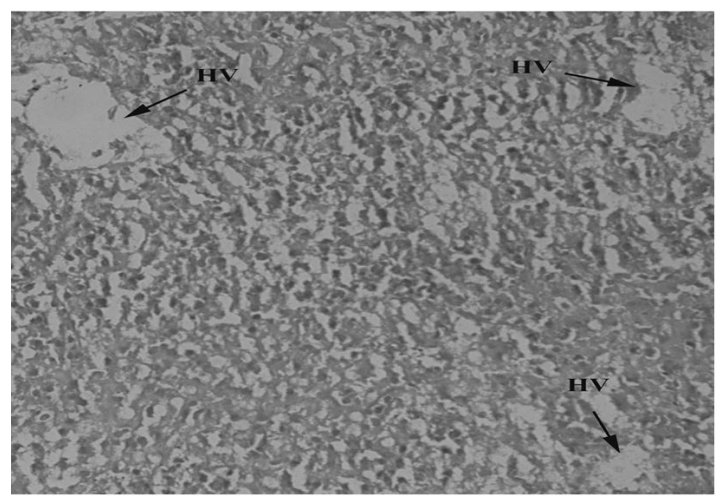

Figure 9. Ictalurus punctatus collected upstream of the entrance into River Chenab CMD showing damage in liver tissues with hepatocytes vacuolization (HV) 40X.

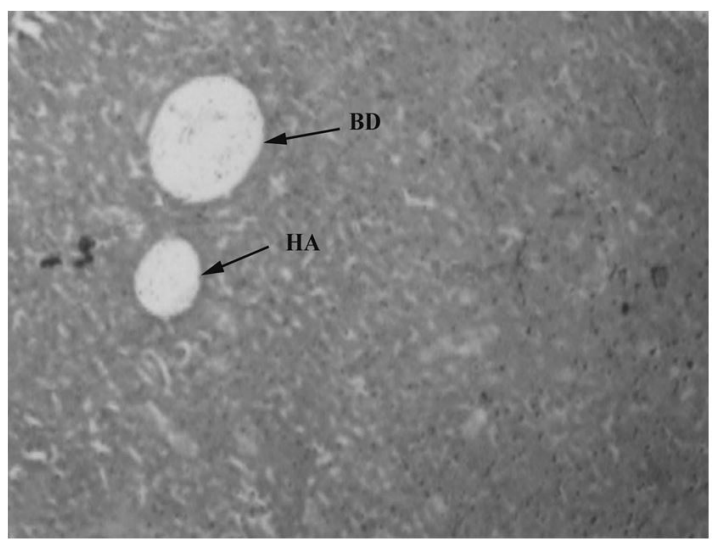

Figure 10. Control freshwater fish Ictalurus punctatus showing normal gill tissues with hepatic artery (HA) and bile duct (BD) $20 \mathrm{X}$.

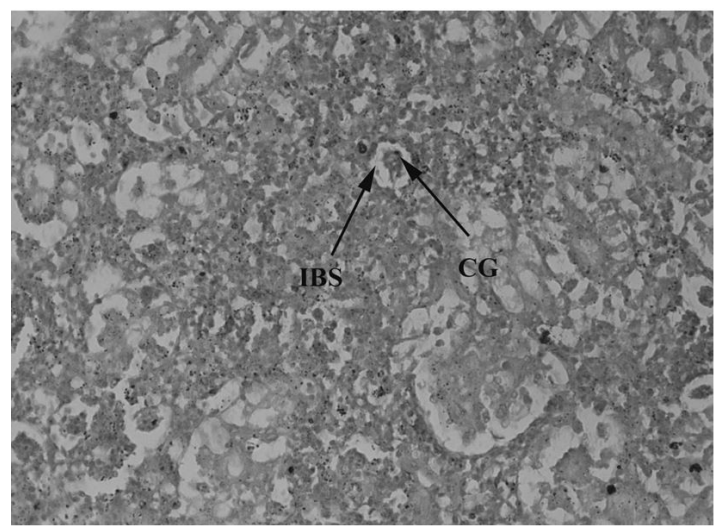

Figure 11. Ictalurus punctatus collected downstream to the entrance into River Chenab CMD showing damage in kidney tissues with increased bowman space (IBS) and constricted glomerulus (CG) 40X.

Muscles contribute to $80 \%$ of fish meals. Muscles were found to be less affected because they are not directly exposed to pollutants. Histopathology of transversely sectioned muscle tissues of catfish collected downstream of

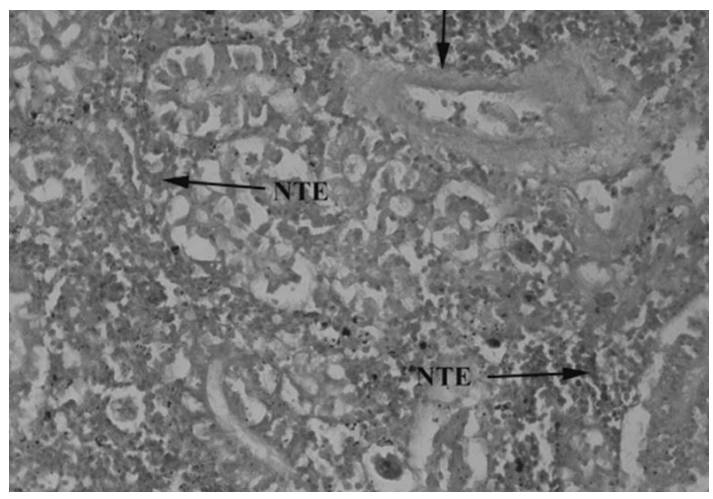

Figure 12. Ictalurus punctatus collected upstream of the entrance into River Chenab CMD showing damage in kidney tissues with necrotic tubular eruption (NTE) and destructive renal tubule (DRT) 40X.

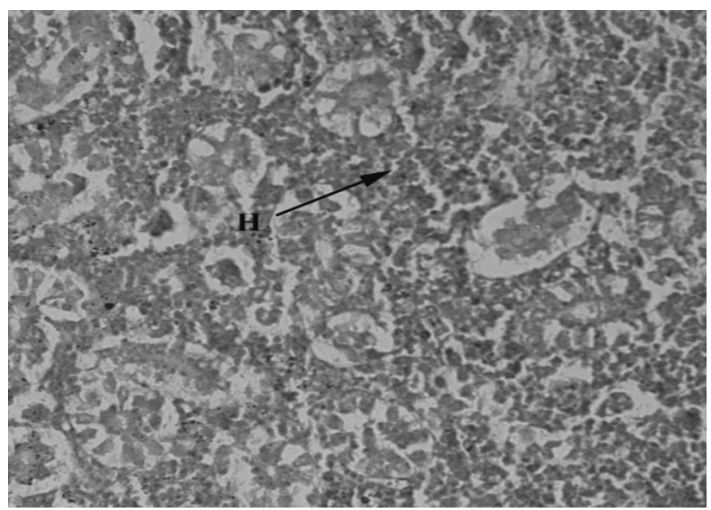

Figure 13. Ictalurus punctatus collected upstream of the entrance into River Chenab CMD showing damage in kidney tissues with hemorrhage $(\mathrm{H}) 40 \mathrm{X}$.

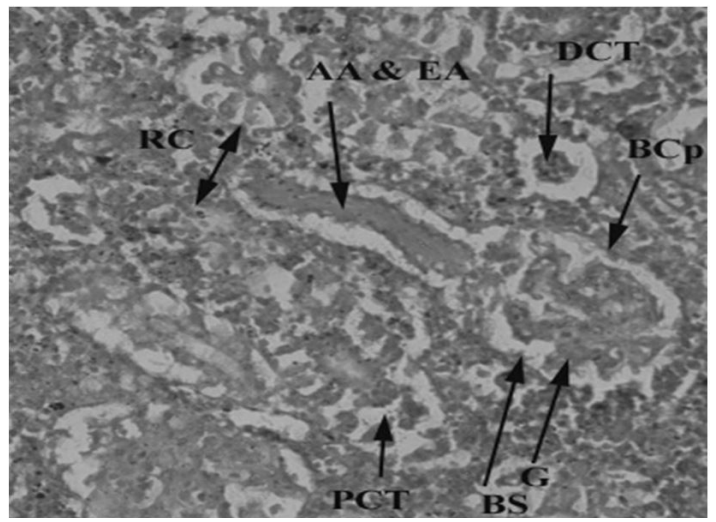

Figure 14. Control freshwater fish (Ictalurus punctatus) showing kidney tissues with normal renal corpuscles (RC), afferent and efferent arterioles (AA \& EA), distal convoluted (DCT), bowmen capsule (BCp), glomerulus (G), bowmen space (BS) and proximal convoluted tubules (PCT) 40X.

CMD showed edema, (Figure 15) Atrophy (Figure 16) and necrosis (Figure 17). Catfish collected from upstream of CMD illustrated intramyofibril space (Figure 18). Histopathology of control catfish tissues indicated muscle fibers with a wispy 
layer of areolar endomysial connective tissue that ensheaths to muscle fibers. These fibers were found to be multinucleate, elongated spindle shaped. Skeletal muscles showed 90 percent muscle fibers and 10 percent connective tissues. Myofibrils having a diameter of 1 micrometre was found to be made of many thick and thin alternating myofilaments (Figure 19).

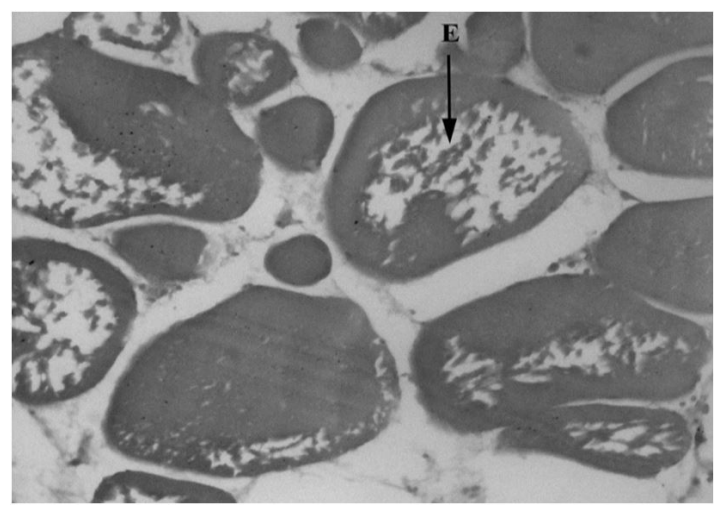

Figure 15. Ictalurus punctatus collected downstream to the entrance into River Chenab CMD showing damage in muscle tissues with oedema in muscle tissue (E) $40 \mathrm{X}$.

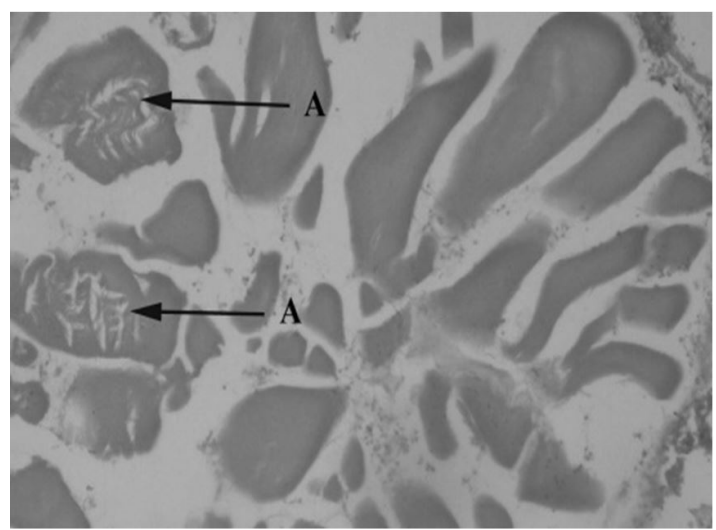

Figure 16. Ictalurus punctatus collected downstream to the entrance into River Chenab CMD showing damage in muscle tissues with atrophy in muscle tissues (A) 40X.

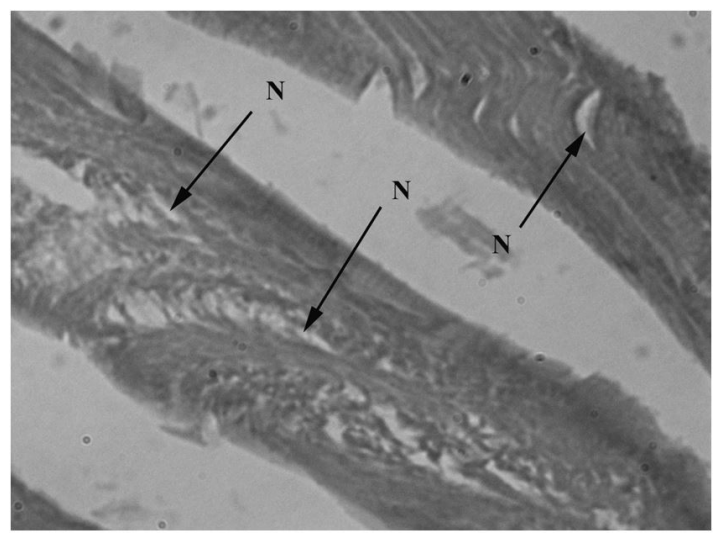

Figure 17. Ictalurus punctatus collected downstream to the entrance into River Chenab CMD showing damage in muscle tissues with necrosis $(\mathrm{N})$ (Hematoxylin \& Eosin stain, 40X).
Fused gill lamellae, inflammatory cell infiltration, hypertrophy, lifting of primary epithelium, fusion and vacuolization were reported in the present study of gills corroborating the findings of Heath (1987) in case of A. malculatus. His studies also emphasized that vacuolation, hyperplasia and lamellar fusion were produced due to polluted water. Uplifting of lamellae might be due to infiltration of fluid between epithelium and basement membrane which ultimately increase diffusion distance for gas exchange. These findings were also found to be in agreement with Santos et al. (2014), Fernandes et al. (2007) and Ezemonye and Ogbomida (2010). Similar anomalies were seen by Liebel et al. (2013) in Oreochromis niloticus and Astyanax aff. fasciatus due to urban sewage and industrial discharge. Vacuolization might be a defense mechanism against injury which affecting the health status of fish.

Liver tissues of catfish showed marked histopathological changes, including vacuolization, hepatocytes degeneration, and increased number of mitochondria, sinusoids dilation and necrosis. Present findings were in agreement with Kalaiyarasi et al. (2017) and Daud et al. (2017) in case of Arius maculatus, while an increase number of mitochondria

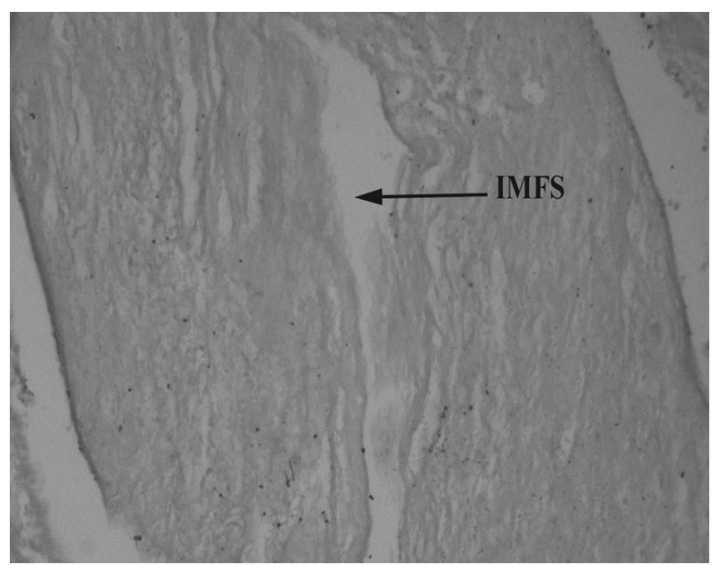

Figure 18. Ictalurus punctatus collected upstream of the entrance into River Chenab CMD showing damage in muscle tissues with intra myofibril space (IMFS) 100X.

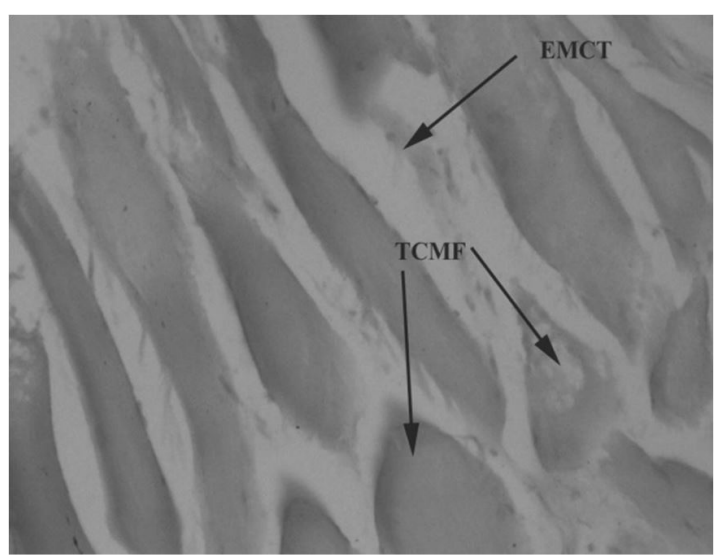

Figure 19. Control freshwater fish (Ictalurus punctatus) showing normal muscle tissues with transversely cut muscle fiber (TCMF), endomycial connective tissues (EMCT) 40X. 
might be due to elevation of enzymatic respiratory activity. Similarity in results was found by Vasanthi et al. (2013) in case of Mugill cephalus due heavy metal pollution in Ennore Estuary. Coherence in results was found by Marchand et al. (2012), Rajeshkumar et al. (2015) and Sina et al. (2015). Parallelism in results was found by Abdel-Moneim et al. (2012) encase of Orechomius niloticus. He stressed that hepatocyte vacuolization and necrosis in parenchymal tissues were induced due to contaminated water with heavy metals of three various locations of Al-Hassa irrigation. Inflammation impairs the flow of portal venous blood, which may be led to sinusoid dilation.

Histopathology of the kidney showed necrosis at tubular epithelium, destructive renal tubules, hemorrhage, increased bowmen space and constricted glomerulus. A similar study was also reported by Camargo and Martinez (2007) in case of prochliodus lineatus due to anthropogenic activities of agricultural, industrial and domestic effluents to Apertados stream. Necrosis of tubular epithelium might be due to toxin, injury and infection, which led to unregulated cell death. Similar results have been obtained by Sarasquete et al. (2003) in case of Mugil and Barbus. They emphasized the glomerulus shrinkage and elevation of bowman capsule space was produced by incidental discharge of Lindane in Barbate River. Dhevakrishnan and Zaman (2012) encase of $L$. Rohita pointed out that degeneration in renal tubules, necrosis and degeneration of glomerulus was due to untreated industrial water, while hemorrhage might be caused due to malformation of renal artery or pre-existing renal tumors. The study was narrated by Mohamed (2009) in case of Tilapia zillii and Solea vulgaris who observed degeneration in renal tubules, hemorrhage, necrosis in focal area and atrophy in glomeruli was caused by agricultural, industrial and domestic wastes discharged into the lake Qarun in Egypt. Similar findings were also reported by Yokote (1982) in case of cyprinus carpio when exposed to sewage.

In these studies, muscle tissue of catfish showed intramyofibril space, degeneration, edema, necrosis and atrophy in muscles. Similar anomalies were also reported by El-Shebly and Elbaghdady (2011) in intense of Nail tilapia where they pointed out focal areas of necrosis, atrophy and vacuolar degeneration in muscle bundle due to oil pollution into River Nile. Thickening and separation of muscle bundle with internal edema, vacuolar degeneration, atrophy and focal area of necrosis was produced due to contaminated water with heavy metals in ponds in Ludhiana was reported by Ullah et al. (2014) in case of C. Carpio. Similar anomalies were reported by Patnaik et al. (2011) in case of C. Carpio. Edema might be caused due to infiltration of fluid into muscle tissues which produces swelling into muscle. The following anomalies were also reported by Mohamed (2009) as the result of different pollutants. Several histopathological alternations were studied by Dhevakrishnan and Zaman (2012) with regard to L. Rohita. They emphasized that necrosis, intra- muscular edema and shortening of muscle bundle was produced due to industrial pollution. Edema, splitting of muscle and hyaline degeneration was observed by Ibrahim (2013) in case of Clarias gariepinus due to contaminated water from El-Rahawy drain of Egypt. These findings will be helpful in assessing environmental monitoring and plan strategies to alleviate the eco-toxicological impacts of pollution magnifying in fresh water, aquatic fauna particular to fish and indirectly to human populations.

\section{Acknowledgements}

The authors (SM, KAH, FAM, and ZA) express their sincere appreciation to the Researchers Supporting Project No. RSP-2020-93 the King Saud University, Riyadh, Saudi Arabia.

\section{References}

ABDEL-MONEIM, A.M.,AL-KAHTANI, M.A. and ELMENSHAWY, O.M., 2012. Histopathological biomarkers in gills and liver of Oreochromis niloticus from polluted wetland environments, Saudi Arabia. Chemosphere, vol. 88, no. 8, pp. 1028-1035. http:// dx.doi.org/10.1016/j.chemosphere.2012.04.001. PMid:22546634.

BOYD, E.C., 1981. Water quality in warm water fishponds. 2nd ed. Opelika, Alabama: Craft Master printers Inc.

CAMARGO, M.M. and MARTINEZ, C.B.J.N.I., 2007. Histopathology of gills, kidney and liver of a Neotropical fish caged in an urban stream. Neotropical Ichthyology, vol. 5, no. 3, pp. 327-336. http:// dx.doi.org/10.1590/S1679-62252007000300013.

DAUD, M., NAFEES, M., ALI, S., RIZWAN, M., BAJWA, R.A., SHAKOOR, M.B., ARSHAD, M.U., CHATHA, S.A.S., DEEBA, F., MURAD, W., MALOOK, I. and ZHU, S.J., 2017. Drinking water quality status and contamination in Pakistan. BioMed Research International, vol. 2017, pp. 7908183. http:// dx.doi.org/10.1155/2017/7908183. PMid:28884130.

DHEVAKRISHNAN, R. and ZAMAN, G., 2012. Cauvery river pollutants induced histopathological changes in kidney and muscle tissues of freshwater fish, Labio rohita (Hamilton, 1822). Online International Interdisciplinary Research Journal : An International Multidisciplinary Journal, vol. 2, no. 5, pp. 9-19.

EL-SHEBLY, A. and ELBAGHDADY, H.A., 2011. Effect of oil pollution on serum growth hormone $(\mathrm{GH})$ levels, histology and ultrastructure of muscles of the Nile Tilapia (Oreochromis niloticus). Egyptian Journal of Aquatic Biology and Fisheries, vol. 15, no. 2, pp. 145-158. http://dx.doi.org/10.21608/ejabf.2011.2086.

EZEMONYE, L. and OGBOMIDA, T.E., 2010. Histopathological effects of Gammalin 20 on African catfish (Clarias gariepinus). Applied and Environmental Soil Science, vol. 2010, pp. 1-8. http:// dx.doi.org/10.1155/2010/138019.

FAROOQ, S., HASHMI, I., QAZI, I.A., QAISER, S. and RASHEED, S., 2008. Monitoring of coliforms and chlorine residual in water distribution network of Rawalpindi, Pakistan. Environmental Monitoring and Assessment, vol. 140, no. 1-3, pp. 339-347. http://dx.doi.org/10.1007/s10661-007-9872-2. PMid:17990069.

FERNANDES, C., FONTAÍNHAS-FERNANDES, A., MONTEIRO, S.M. and SALGADO, M.A., 2007. Histopathological gill changes in wild leaping grey mullet (Liza saliens) from the EsmorizParamos coastal lagoon, Portugal. Environmental Toxicology, vol. 22, no. 4, pp. 443-448. http://dx.doi.org/10.1002/tox.20269. PMid:17607735. 
HEATH, A.G., 1987. Behavior and nervous system function in water pollution and fish physiology. Boca Raton: RC Press, pp. 181-196.

IBRAHIM, S.A., 2013. Effect of water quality changes on gills and kidney histology of Oreochromis niloticus fish inhabiting the water of Rosetta branch, River Nile, Egypt. World Applied Sciences Journal, vol. 26, no. 4, pp. 438-448.

KALAIYARASI, T., JAYAKUMAR, N., JAWAHAR, P., AHILAN, B. and SUBBURAJ, A., 2017. Histological changes in the gill and liver of marine spotted catfish, Arius maculatus from sewage disposal site, Therespuram off Thoothukudi, Southeast coast of India. Journal of Entomology and Zoology Studies, vol. 5, pp. 1710-1715.

KIM, K.-H., KABIR, E. and JAHAN, S.A., 2016. A review on the distribution of $\mathrm{Hg}$ in the environment and its human health impacts. Journal of Hazardous Materials, vol. 306, pp. 376-385. http://dx.doi.org/10.1016/j.jhazmat.2015.11.031. PMid:26826963.

LIEBEL, S., TOMOTAKE, M.E.M. and OLIVEIRA-RIBEIRO, C.A., 2013. Fish histopathology as biomarker to evaluate water quality. Ecotoxicology and Environmental Contamination, vol. 8, no. 2, pp. 9-15. http://dx.doi.org/10.5132/eec.2013.02.002.

MARCHAND, M., VAN DYK, J.C., BARNHOORN, I.E. and WAGENAAR, G.M., 2012. Histopathological changes in two potential indicator fish species from a hyper-eutrophic freshwater ecosystem in South Africa: a baseline study. African Journal of Aquatic Science, vol. 37, no. 1, pp. 39-48. http://dx.doi.org/10.2 989/16085914.2011.636902.

MARTIN, P., NISHIDA, J., AFZAL, J., AKBAR, S., DAMANIA, R. and HANRAHAN, D., 2006. Pakistan strategic country environmental assessment. Washington: South Asia Environment and Social Development Unit, World Bank. vol. 1.

MILLER, S.M. and MITCHELL, M.A., 2009. Ornamental fish. In: M. MITCHELL and T. TULLY, eds. Manual of exotic pet practice. St. Louis: Elsevier, pp. 39-72. http://dx.doi.org/10.1016/ B978-141600119-5.50007-X.

MOHAMED, F., 2009. Histopathological studies on Tilapia zillii and Solea vulgaris from Lake Qarun, Egypt. World Journal of Fish and Marine Sciences, vol. 1, no. 1, pp. 29-39.

PAITHANE, K.T., SONAWANE, D.L., BHANDARE, R.Y. and MORE, P.R., 2012. Histophatological changes due to induced dimethoate in the liver of freshwater fish Channa punctatus from river Shivana, Aurangabad (MS) India. The Ecoscan, vol. S1, pp. 213-217.

PATNAIK, B.B., HOWRELIA, H., MATHEWS, T. and SELVANAYAGAM, M., 2011. Histopathology of gill, liver, muscle and brain of Cyprinus carpio communis L. exposed to sublethal concentration of lead and cadmium. African Journal of Biotechnology, vol. 10, no. 57, pp. 12218-12223.
RAJESHKUMAR, S., KARUNAMURTHY, D., HALLEY, G. and MUNUSWAMY, N., 2015. An integrated use of histological and ultra-structural biomarkers in Mugil cephalus for assessing heavy metal pollution in east Berbice-Corentyne, Guyana. International Journal of Bioassays, vol. 4, no. 11, pp. 4541-4554.

SANTOS, D.M., MELO, M.R.S., MENDES, D.C.S., ROCHA, I.K., SILVA, J.P., CANTANHÊDE, S.M. and MELETTI, P.C., 2014. Histological changes in gills of two fish species as indicators of water quality in Jansen Lagoon (São Luís, Maranhão State, Brazil). International Journal of Environmental Research and Public Health, vol. 11, no. 12, pp. 12927-12937. http://dx.doi. org/10.3390/ijerph111212927. PMid:25514148.

SARASQUETE, C., ORTIZ-DELGADO, J.B. and GONZÁLEZ DE CANALES, M.L., 2003. Histopathological changes induced by lindane $(\gamma-\mathrm{HCH})$ in various organs of fishes. Scientia Marina, vol. 67 , no. 1 , pp. 53-61.

SCHWAIGER, J., FERLING, H., MALLOW, U., WINTERMAYR, H. and NEGELE, R.D., 2004. Toxic effects of the non-steroidal anti-inflammatory drug diclofenac: Part I: histopathological alterations and bioaccumulation in rainbow trout. Aquatic Toxicology, vol. 68, no. 2, pp. 141-150. http://dx.doi.org/10.1016/j. aquatox.2004.03.014. PMid:15145224

SINA, I., ZAHARAH and SABRI, M.S.M., 2015. Larvicidal activities of extract flower Averrhoa bilimbi L. Towards important species mosquito, Anopheles barbirostris (Diptera: culicidae). International Journal of Zoological Research, vol. 12, no. 1-2, pp. 25-31.

SULTANA, T., BUTT, K., SULTANA, S., AL-GHANIM, K.A., MUBASHRA, R., BASHIR, N., AHMED, Z., ASHRAF, A. and MAHBOOB, S., 2016. Histopathological changes in liver, gills and intestine of Labeo rohita inhabiting industrial waste contaminated water of river Ravi. Pakistan Journal of Zoology, vol. 48 , no. 4, pp. 1171-1177.

ULLAH, S., JAVED, M.W., SHAFIQUE, M. and KHAN, S., 2014. An integrated approach for quality assessment of drinking water using gis: a case study of Lower Dir. Journal of Himalayan Earth Sciences, vol. 47, no. 2, pp. 163-174.

VASANTHI, L.A., REVATHI, P., MINI, J. and MUNUSWAMY, N., 2013. Integrated use of histological and ultrastructural biomarkers in Mugil cephalus for assessing heavy metal pollution in Ennore estuary, Chennai. Chemosphere, vol. 91, no. 8, pp. 1156-1164. http:// dx.doi.org/10.1016/j.chemosphere.2013.01.021. PMid:23415490.

WORLD HEALTH ORGANIZATION - WHO 2013 [viewed 20 October 2013]. Guidelines for drinking water quality, WHO Water Quality and Health Strategy 2013-2020. Available from: http://www.who.int/water_sanitation_health/dwq/en/

YOKOTE, M., 1982. Digestive system. In: T. HIBIYA, ed. An atlas of fish histology-normal and pathological features. Tokyo: Kodansha Ltd., pp. 74-93. 